IZA DP No. 8926

The Winner Takes It All:

Internal Migration, Education and Wages in Ethiopia

Niels-Hugo Blunch

Caterina Ruggeri Laderchi

March 2015 


\title{
The Winner Takes It All: Internal Migration, Education and Wages in Ethiopia
}

\author{
Niels-Hugo Blunch \\ Washington and Lee University \\ and IZA \\ Caterina Ruggeri Laderchi \\ World Bank
}

Discussion Paper No. 8926

March 2015

IZA

P.O. Box 7240

53072 Bonn

Germany

Phone: +49-228-3894-0

Fax: +49-228-3894-180

E-mail: iza@iza.org

\begin{abstract}
Any opinions expressed here are those of the author(s) and not those of IZA. Research published in this series may include views on policy, but the institute itself takes no institutional policy positions. The IZA research network is committed to the IZA Guiding Principles of Research Integrity.

The Institute for the Study of Labor (IZA) in Bonn is a local and virtual international research center and a place of communication between science, politics and business. IZA is an independent nonprofit organization supported by Deutsche Post Foundation. The center is associated with the University of Bonn and offers a stimulating research environment through its international network, workshops and conferences, data service, project support, research visits and doctoral program. IZA engages in (i) original and internationally competitive research in all fields of labor economics, (ii) development of policy concepts, and (iii) dissemination of research results and concepts to the interested public.
\end{abstract}

IZA Discussion Papers often represent preliminary work and are circulated to encourage discussion. Citation of such a paper should account for its provisional character. A revised version may be available directly from the author. 


\section{ABSTRACT \\ The Winner Takes It All: Internal Migration, Education and Wages in Ethiopia*}

Previous studies of migration have mainly examined international dynamics. Yet, internal migration is an important issue, especially in Sub-Saharan Africa. Using the 2001 Ethiopia Child Labor Survey, a nationally representative household survey, this paper examines internal migration in Ethiopia, focusing on the linkages among internal migration, education and wages. The results suggest that migrants are better educated and obtain higher wages than non-migrants, controlling for other factors (including education), and also obtain higher returns to their education. In other words, the more educated reap higher returns from their education as a main effect, as well as higher returns to their education from migration than non-migrants - that is, "the winner takes it all." This result should be of concern to policy makers in Ethiopia and elsewhere - especially in Sub-Saharan Africa - since individuals with low levels of education already are in a vulnerable group. The study therefore also discusses the policy implications of these results.

JEL Classification: J24, J31, O15

Keywords: $\quad$ internal migration, wages, education, Ethiopia

Corresponding author:

Niels-Hugo Blunch

Washington and Lee University

Lexington, VA 24450

USA

E-mail: blunchn@wlu.edu

\footnotetext{
* We thank Charles Teller and other participants at the Annual Meeting of the Population Association of America (Boston), Tyler Dickovick, and Joseph Guse for helpful comments and suggestions. Remaining errors and omissions are our own. The views expressed here are those of the authors and should not be attributed to the World Bank or any of its member countries or affiliated institutions.
} 


\section{Introduction}

While there are many ways to improve one's livelihood, two stand out in particular. The first, and arguably most important, is through improving one's education. This is the basis for the study of human capital (Becker, 1964; Mincer, 1974). This literature generally finds that returns to education are substantial across countries, including Sub-Saharan Africa (Psacharopoulos, 1994; Psacharopoulos and Patrinos, 2004).

The second way is potentially more immediately rewarding: changing one's economic conditions geographically through migration. The literature here has mainly been focused on international migration, that is, looking at how individuals who leave their country of originfrequently migrating from developing to developed countries - fare in their "new" country, mostly in terms of employment and/or wages and incomes (Ajakaiye, Lucas and Karugia, 2006; Faini, de Melo and Zimmermann, 1999). Far less is known about internal migration within developing countries themselves, though recently there has been increased focus on this area of study (Beegle et al., 2011; de Brauw et al., 2014). ${ }^{1}$

This paper examines the returns to migration in Ethiopia, examining a nationally representative household survey. We explore four main research questions, as follow. (1) Is there a wage premium to migration? (2) Does the share of migrants in the current (i.e., receiving) community matter for wages? (3) Is the overall wage structure of migrants and non-migrants in the receiving community different? (4) Does the migration-wage association differ across educational attainment; in particular, are the returns to education the same for migrants and nonmigrants? The combined results suggest that more educated migrants gain the most from increased migration, while less educated migrants have lower returns. We also find a base effect of positive returns to education in our research, which reflects a well-established finding in the literature. Combined, these effects mean that more educated migrants reap higher returns both from benefitting from migration and from being better educated to begin with - that is, "the winner takes it all." This result should be of concern to policy makers in Ethiopia, since individuals with low levels of education already are in a vulnerable group. Policy focus should therefore be shifted even more towards this group - for example in terms of skills upgrading and education - especially in areas with high levels of in-migration.

\footnotetext{
${ }^{1}$ See also Todaro (1980) and Lucas (1997) for a review of the earlier literature.
} 
The remainder of this paper is structured as follows. The next section provides the institutional and historical background of migration in Ethiopia, while Section Three presents the previous evidence on internal migration and living conditions in developing countries, with a focus on the Ethiopian experience. Section Four develops the conceptual and empirical framework, while Section Five presents the data and descriptive analysis. The results are presented in Section Six. Finally, Section Seven concludes, discusses policy implications, and provides suggestions for further research.

\section{Background: Migration in Ethiopia ${ }^{2}$}

Internal migration has been relatively low in Ethiopia by international standards (World Bank, 2007: 110), but it has always been one of the main vehicles for urbanization in the country — as it has been in other countries, also. In Ethiopia, as in other countries, there are many different possible reasons motivating migrants - typically grouped into "push" and "pull" factors, where the former denote (negative) characteristics in the area of origin and the latter denote (positive) characteristics in the area of destination.

"Push" factors include shortages of land, low agricultural productivity, and high population densities in northern Ethiopia, along with recurrent droughts throughout the country. This in turn led to the creation of garrison towns in the south, southwest and eastern parts of Ethiopia as early as the early 1900s. This tendency was reinforced with the establishment of Addis Ababa as the permanent capital, with the associated permanent need for labor and goods and services. This source of labor demand became a "pull" factor to the country's largest city, which was amplified by improvements in infrastructure and transportation links - most notably the creation of the Djibouti-Addis Ababa railway. In turn, the construction of the railway helped contribute to the emergence of several towns along the route and, along with them, also the emergence of financial and public services including banks, hospitals and schools. Urban infrastructure was further consolidated through the 1940s with the emergence of markets and the associated increased division of labor, increased specialization and the emergence of a cash economy.

In turn, the growth of towns and cities worked to help encourage the migration of nonagricultural workers from rural areas - especially artisans, traders, bar and restaurant owners,

\footnotetext{
${ }^{2}$ This section draws substantially on World Bank (2007: Ch 4), where more details can be found.
} 
shop-keepers and construction workers - thus effectively becoming a "pull" factor for prospective migrants. This continued through the post-WWII period, where the combination of the consolidation and centralization of government structures, the renewed emphasis on road building, the emergence of industrial enterprises and commercial centers, the designation of industrial zones along the railroad, among other things, led to increased urban growth, especially the emergence of small commercial towns.

In addition to the rural-urban migration, however, Ethiopia started experiencing increased rural-rural migration. This was especially linked to the emergence of commercial agricultural sites. In 1976, for example, 75 percent of the farm workers engaged in 16 irrigation schemes in the Awash valley were immigrants, mostly from other rural areas facing considerable land pressure (World Bank, 2007: 116). Similarly, the development of coffee production in the southwest also attracted labor, both seasonal and permanent, and led to the development of new towns. In the early 1970s, for example, seasonal migration to the coffee-producing areas was estimated at 50,000 (World Bank, 2007: 116). Political and economic changes under the Marxist-Leninist Derg regime in the 1970s - most notably the confiscation of private lands, the closure of private mechanized agriculture, the introduction of a pass system and check-points along the main highways - led to a temporary halt in migration and therefore also slowed high urbanization rates. However, intensified conflict during the country's civil war led to the resumption of large inflows of migrants into cities between 1984 and 1994, a period in which the present regime came to power (World Bank, 2007: 117).

Urban centers increased in importance and attraction as destinations for migrants during the post revolutionary period due to the opening of branch offices of mass organizations, government and non-governmental agencies all of which created opportunities at district, provincial and regional levels of the country (Mberu, 2006). Internal migration in Ethiopia also tend to have a substantial marriage-related component, including divorce: people may decide to migrate to get married but due to a divorced woman being socially unaccepted and therefore frequently under pressure to leave her place of current residence to instead migrate to nearby urban centers divorce may also be a motivating factor for the migration decision (Mberu, 2006).

In recent years, starting with the government taking power in 1991, the country has been undergoing a major transformation from a centrally planned to a market-oriented economy (Mberu, 2006). Internal migration tends to increase in importance during such times of 
transformation, both demographically and economically (Kiros and White, 2004), in turn suggesting an increased importance of internal migration in Ethiopia in recent years.

Today people are, in principle, free to move around within Ethiopia as long as they carry a personal ID at all times. In practice there are some constraints, however, including social constraints (most notably concerning adult women). In addition, movement away from urban areas requires an official letter from the local kebele. ${ }^{3}$ Movement from rural areas does not have a similar requirement - though it is generally deemed useful to clear a potential move with the local kebele. The reason for this includes evidence that kebeles will claim that out-migrants have forfeited land rights if their migration persists beyond a certain duration, or the emigrant engages in non-farm activities (e.g., trading in consumer goods) (World Bank, 2007: 118). This unambiguously leads to at least some restrictions on physical mobility (and raises the costs of income diversification strategies that combine farm and off-farm economic activities in rural areas).

Thus, internal migration has been a major phenomenon in Ethiopia in recent years and continues to play a role today, despite some constraints on mobility. Both push and pull factors are important in motivating migrants, who frequently are very different than non-migrants regarding their skills, education and intrinsic characteristics. In short, we expect those who move to differ from those who remained in their village, town or city.

\section{Previous Research on Internal Migration with a Focus on Ethiopia}

Most of the previous research on migration has focused on international migration, though recently there seems to be increased focus on internal migration. ${ }^{4}$ One of the reasons for the relative paucity of studies on internal migration - especially in sub-Saharan Africa-is that nationally representative, multi-purpose household surveys often lack a distinct migration module (de Brauw, Mueller and Lee, 2014). If we are interested in living standards, as measured by consumption, income and/or wages, the relevant data sources become even scarcer, as “...many otherwise useful data sources lack direct measures of living standards...” (O’Donnell et al. (2008: 71).

\footnotetext{
${ }^{3}$ The smallest administrative unit of Ethiopia (corresponds to a ward or neighborhood).

${ }^{4}$ See Todaro (1980) and Lucas (1997) for a review of the earlier research on internal migration in developing countries.
} 
Using an unusually well suited, rich, panel dataset in a carefully conducted study, Beegle et al. (2011) estimate the causal effect of internal migration in Tanzania using a variety of estimation strategies, including benchmark OLS panel/fixed effects and instrumental variables approaches. They find, for their main result, a substantial impact of internal migration on annual per-capita household consumption growth in the order of 36 percentage-points over the thirteenyear period covered by their panel. This result is robust to a range of different estimation strategies and various other sensitivity checks, including alternative definitions of the consumption measure.

Studies such as this are rare, given the data deficiencies when the objective of study involves migration and various measures of living standards. Yet related studies exist for Ethiopia, as well. These studies are mostly based on two data sources, namely the Ethiopian Rural Household Survey (ERHS), a panel survey of 18 villages in rural Ethiopia conducted periodically since 1994, and (to a lesser extent) the Ethiopian Migration and Health Survey (EMHS), conducted in five regions of Ethiopia in 1998. Among the most relevant studies for our questions is de Brauw et al. (2013), which focuses on the two most recent rounds of the ERHS (conducted in 2004/05 and 2009, respectively). The main objective is to examine the possible impact of migration on overall well-being, using both objective (consumption) and subjective (happiness) measures and several different methodologies-including OLS, IV and differencein-difference matching. The main result is that migration increases per capita household consumption by about 110 percent. The authors take this to suggest that "barriers exist, even within countries such as Ethiopia, against the free movement of people to places where they would be objectively better off" (de Brauw et al., 2013: 1).

In a related study, Mberu (2006) examines internal migration and household living conditions in Ethiopia using the 1998 EMHS. Since the survey included neither income measures nor consumption expenditures, the author constructed a household living condition index based on (a) the physical quality of their residence (materials used for the wall, the roof and the floor, as well as the main source of light, the nature of bathing and toilet facilities, and the number of rooms in the house) and (b) asset ownership (including means of personal transportation (car, bicycle) and other household durables (including radio, television, sofa, electric fan, electric iron, electric stove, electric mitad (grill), clock, insecticide sprayer, cassette recorder, cylinder, telephone, refrigerator, cart and plough). To construct the main dependent 
variable, Mberu subsequently aggregated these indicators into a living standards index using principal component analysis. Using OLS, Mberu regressed this aggregated living standards index on migration status and other potentially important variables. While descriptive statistics suggested permanent migrants experienced better living conditions overall than non-migrants, and temporary and return migrants, this result gets overturned once controls are included in the multivariate analysis. The distinction ends up being between temporary migrants and other groups. Indeed, temporary migrants are about 36 percent worse off than non-migrants, while permanent and return migrants are both on par with non-migrants (their coefficients being statistically insignificant from the latter). The author takes this to indicate that the living conditions advantage of (permanent) migrants over non-migrants from the descriptive analysis are primarily due to selectivity into migration status, especially through education and occupation. $^{5}$

From this brief review of previous research on internal migration and economic wellbeing two things are clear. First, while previous research on migration and its potential consequences has mainly focused on international migration to developed countries there now exist a substantial, and growing, literature focused on internal migration in developing countries, as well. Second, however, several issues have challenged this research. Most importantly, information on migration - and, to a lesser extent, on income and wages - is rudimentary and even absent for many household surveys in developing countries. As a corollary of this, information on the wages or income of migrants is even harder to come by. Additionally, some surveys designed especially to study migration suffer (possibly due to the cost of conducting such highly specialized surveys) from not being nationally representative-being conducted either for only a limited number of regions within a country or only being conducted in rural areas, or both. In either case, any resulting findings may not necessarily be conducive for policy at the national level. Additionally, since rural-urban migration constitutes a large part of overall internal migration in developing countries, focusing only on rural areas is less than ideal and limits possible useful policy recommendations. These issues were all prevalent in previous research on internal migration in Ethiopia. By addressing all these issues simultaneously, this

\footnotetext{
${ }^{5}$ Additional studies on internal migration Ethiopia-though with an emphasis of other aspects of internal migration in Ethiopia and therefore not directly relevant for our study - include de Brauw and Mueller (2012), which examines the possible impact of limitations in land rights transferability on internal migration and Gray and Mueller (2012), which studies the possible impact on drought and internal migration (both studies examine the ERHS and therefore also implicitly focus on rural Ethiopia, only).
} 
study adds to the literature on the nexus of internal migration and economic well-being in developing countries in general, adding particularly to our knowledge for the specific case of Ethiopia.

\section{Methodology}

To help frame the subsequent analysis, we consider a conceptual framework in which wages are determined by education and other characteristics, including migration status. In essence, this is an augmented Becker-Mincer human capital model in which migration status is considered as an additional, particularly important correlate of wages. Specifically, wages are assumed to be a function of education $(E)$; other observed individual background characteristics including age, gender and geographical location $(B)$; and migration status and the share of migrants in the (current/receiving) community $(M)$, giving rise to the following wage function:

$$
W=W(E, B, M)
$$

In (1), an increase in education leads to an increase in wages, holding the other factors constant. In addition to this standard result from the Becker-Mincer framework, the inclusion of migration variables allows for potentially different returns to migrants and non-migrants and for network effects to affect wages, holding the other factors constant. This follows the insight of Todaro (1980: that “...migrants ... tend to be disproportionately young, better educated, less riskaverse, and more achievement-oriented and to have better personal contacts ${ }^{6}$ in destination areas than the general population in the region of out-migration."

Based on the previous discussion, we will explore the following four questions in the empirical analysis. First, is there a premium to migration? In other words, are wages and migration status positively correlated? Here, one might conjecture a positive relationship, since migrants may have more diverse labor market experiences, for example, essentially bringing with them their labor market experience from their "old" community. Second, does the share of migrants in the current (receiving) community matter? Here, one might expect a negative association between the share of migrants in the community and individual wages, due to the increased competition from migrants depressing wages. At the same time, it is also possible that access to networks in the community of destination increases the probability of obtaining a job, for example through decreasing the psychic costs of relocating, decreasing the financial costs of

\footnotetext{
${ }^{6}$ The inclusion of network effects is more specifically inspired by Munshi (2003).
} 
relocating, or more generally simply increase the information available to potential migrants (Lucas, 1997: 743) — or the influx of migrants may cause emigration of natives. The net effect is therefore ambiguous. Third, is the overall wage structure of migrants and non-migrants different? For example, one might expect the returns to education to be higher for migrants, due to migrants effectively bringing with them a more diverse labor market experience (i.e. labor market experience both from the current (receiving) community and the community of origin). Fourth, does the migration-wage association differ across educational attainment? For example, one might expect the less educated to be harder hit—in terms of their wages — by an influx of migrants.

Moving to the estimation strategy, it is not clear a priori how exactly (1) should be estimated empirically. For example, (1) can only be estimated for individuals receiving a wage - making the sample a select one, or similarly, implying that labor supply is endogenous. To explore this further, we initially experimented with Heckman-type models to allow labor supply to be endogenous, using variables for children in the household, marital status and marital status interacted with gender to identify the selection equation but found only modest evidence supporting this more complicated - and assumption-intensive — estimation procedure.

Another issue is the potential endogeneity (selectivity) of migration status - stemming from the fact that our migration status measure is potentially prone to simultaneity, measurement error, and omitted variables issues. Indeed, some of the potentially important drivers of the migration decision discussed previously are not (easily) measurable (risk-aversion, achievementorientation) - and will therefore get picked up by the migration variable, thus potentially leading to omitted variables bias.

Hence, in a model where the only migration variable included was the migration status of the household, we also experimented with endogenizing migration status, using the density of migrant households in the community of residence. This, too, turned out to support the more

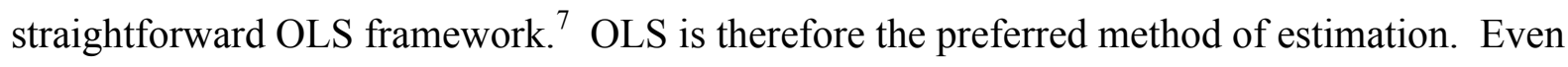
so, we emphasize that one should be careful not to attribute an explicit causal interpretation to subsequent results - but rather treat them as suggestive of one or more causal mechanisms possibly being at play. In particular, we propose using the results in McKenzie et al. (2010),

\footnotetext{
${ }^{7}$ Additionally, using the density of migrant households in the community of residence as instrument of migration status also would of course also make it infeasible to allow this variable to have a direct effect on wages - which would be unfortunate, given the motivation given above for the existence of such a direct effect.
} 
which compares findings from exploring a unique combination of experimental and nonexperimental migration data in New Zealand, to effectively bound the migration effect found here.

In order to address the research questions mentioned previously, models are also estimated separately for females and males, migrants and non-migrants, and by educational attainment. This allows us to explore the possibility of the wage structure differing across these dimensions, especially as pertains to the migration and education variables. The main objective here is to determine which part(s) of the Ethiopian work force is/are particularly affected by migration.

To ensure the survey results are nationally representative, the estimations incorporate sampling weights, stratification and clustering (Wooldridge, 2010). This implicitly allows for arbitrary heteroskedasticity, and for this reason we estimate Huber-White standard errors (Huber, 1967; White, 1980).

\section{Data and Descriptive Analysis}

The empirical analyses of this paper examine household survey data for Ethiopia. The Ethiopia Child Labor Survey (CLS) is a nationally representative ${ }^{8}$ multi-purpose household survey, carried out in 2001. Using the 1994 Population and Housing Census of Ethiopia as the sampling frame, an initial sample of 1,257 enumeration areas (EAs) was first established. Based on the results from the 1999 National Labor Force Survey, it was found that about 35 households per EA would yield the desired level of precision for subsequent analyses. Of the initial 43,995 households targeted for the survey, 43,601 (99.1 percent) were ultimately covered. In the households covered by the survey, all household members were asked about information such as their gender, age, education, and labor market information, including labor market status and wages. A special child labor module asked additional information of children 5-17 years of age. Lastly, a household module asked household level information, including whether the household had ever lived elsewhere, and if so the reason for the move, and the time in the current residence. A particularly appealing feature of this survey is that both information on wages and migration

\footnotetext{
${ }^{8}$ Apart from non-sedentary areas of two zones of the Affar Region and six zones of the Somali Region, residents of collective quarters, homeless and foreigners (see CSA (2002), whereupon the following discussion is based, and where more detail of the survey can be found).
} 
status are available, which is not very common - in particular, the lack of income/wage data seems widespread, even in otherwise prominent and useful surveys. ${ }^{9}$

The wage measure (the dependent variable) is based on information on cash and in-kind payments and the period/term of payment, thus allowing us to create a variable for hourly total wages (i.e. the sum of cash and in-kind payments divided by hours worked). ${ }^{10}$ Initial tabulations of this hourly wage measure revealed some extreme observations in the upper tail of the wage distribution, so we trimmed off all wages $65 \mathrm{birr} /$ hour and above $^{11}$ — which, however, amounts to less than 0.5 percent of the effective estimation sample.

Among the explanatory variables, the main variable of interest is migration status. The migration status measure is based on information on household level migration. Specifically, the Survey asks "Has this household ever lived outside of this town/rural part of this wereda [district] as usual residence?" If so, the Survey goes on to ask "How long has this household been living in the present place of residence?" Response categories include less than a year, one year, two years, and so on. We construct a (binary) measure of recent migration, which is defined as one if the household has been living in the current location for 4 years or less, and zero otherwise.

One potential issue with this is that this measure implicitly assumes that all household members "share" the migrant status. While this is consistent with the so-called New Economics of Labor Migration view (Stark, 1991; Stark and Bloom, 1985) according to which migration might better be seen as a household rather than an individual decision, it still seems worthwhile to at least try to corroborate the extent to which this household-based migration measure agrees with an individual-based one, by using other available data. To help support such efforts, the Ethiopia Labor Force Survey (LFS) from 1999 fortunately includes information on individual

\footnotetext{
${ }^{9}$ Indeed, as stated by O’Donnell et al. (2008: 71) "Both income and consumption data are expensive and difficult to collect, and many otherwise useful data sources lack direct measures of living standards (e.g., the Demographic and Health Surveys [DHS]).” The 2000 and 2011 Demographic and Health Surveys (DHS) for Ethiopia, for example, only include information about whether or not individuals receive any wages but not how much and also do not include any information on migration. On the other hand, a survey such as the 1998 Migration, Gender and Health Survey in Five Regions of Ethiopia, which was specifically designed to study migration in Ethiopia, was conducted in only five regions of Ethiopia and therefore not nationally representative. The nationally representative 2001 Ethiopia Child Labor Survey examined here, though arguably not very recent, therefore still seems to be a very useful survey for the analysis proposed here, with the focus on the linkages among (internal) migration, education and wages.

${ }^{10}$ Except for workers reporting "piece rate" (work paid for according to a set rate per unit) as the period/term of payment, since no information is collected on the work hours associated with total earnings for this case.

${ }^{11}$ In 2001 (the year of the survey) the exchange rate was about 8.5 birr to 1 USD.
} 
level migration status. ${ }^{12}$ While household-level migration information might be thought to overstate individual-level migration status by implicitly applying the status of migrant to all household members, the wording of the question in the CLS on which this information is based seems somewhat restrictive, talking about "the" household. It is therefore not a priori clear whether our measure overstates or understates "true," individual-level migration.

To provide a rough check of the validity of approximating individual-level migration status with this household-based measure, we compare the incidence of recent migration in the LFS and the CLS (Table 1). Being only two years apart, there should not be really massive differences in the incidence in recent migration - if our household-based migration measure is valid. While Table 1 reveals differences in the migration incidence when comparing the two measures — with the LFS consistently yielding a higher migration incidence than the CLS - the results do not appear irreconcilable. With the caveat that the measure is systematically somewhat downward biased relative to individual-level migration, we therefore proceed with our household-based migration measure.

\section{[Table 1 about here]}

In addition to the migration status variable, we also include a variable for the share of migrants in the community. This is defined using the migration status variable, so that we effectively have to assume that all members of a "migration household" are also all themselves migrants. Again, this variable is an attempt to measure the potential competition from inmigrants.

Education variables obviously have a prominent role in the human capital framework. We define this as a series of dummy variables, based on information on the highest grade completed. Due to the many categories (including grades 1-12, university, literacy campaigns, etc.), we create a total of six dummies: No education (reference), Grade 1-4, Grade 5-8, Grade 912, Above grade 12, and Literacy campaign and other non-formal education.

Additionally, we include a full set of dummy variables for region of residence. These capture a host of factors associated with region of residence, including quality of education and local labor market conditions. While we are not specifically interested in these factors per se, conducting the analysis net of these factors helps decrease any bias of the pertinent coefficients.

\footnotetext{
${ }^{12}$ The LFS, however, does not include wage or earnings information, which therefore makes it unsuitable for the main analysis of this paper.
} 
The initial sample of 189,936 men, women, and children is initially restricted to employed adults 15 years of age and above living in urban areas, who were not piece rate enumerated. ${ }^{13}$ Especially due to the low level of formal employment (and therefore relatively few wage earners) in Ethiopia, this yields an initial, potential estimation sample of 10,511 observations. Due to the trimming of extreme observations on wages and missing observations on one or more of the explanatory variables the final, actual estimation sample contains 10,414 employed adults from urban areas.

After discussing the variable definitions and sample restrictions, it seems fruitful to get a first look at the data in terms of sample means in various dimensions. First, it would seem interesting to explore the reasons why people in the sample migrate in the first place. ${ }^{14}$ From Table 2, people predominantly move for work-related reasons, either to look for a job (about 20 percent) or because they actually found a job and/or received a job transfer (about 62 percent). The reason for moving for work-related reasons was greater among males than among females (about 21 percent of males versus about 18 percent of females came from households that moved due to looking for a job; and about 65 percent of males versus about 55 percent of females came from households that moved due to having been transferred and/or found a job).

[Table 2 about here]

Next, when considering the full sample, how are the females, males, migrants, and nonmigrants faring in terms of wages, education, and migration status (if applicable)? From Table 3, male wages exceed female wages (again, a well-established phenomenon for developed and developing countries alike). More importantly for our purposes, the raw wage gap seems to favor migrants heavily, at almost 25 percent higher hourly wages than non-migrants. In addition to the higher wages on average, migrants are also more educated than non-migrants on average. So, based on the descriptive statistics, migrants seem to be better faring than non-migrants, both in terms of education and wages. However, this is based on simple correlations and does not take into account other variables - for example, migrants may not obtain higher wages when other factors are controlled for (including their education); likewise, migrants may not

\footnotetext{
${ }^{13}$ Again, as discussed earlier, hourly wages cannot be calculated for piece rate workers for this dataset. The focus on urban areas is due to wage employment being much less prevalent-if not virtually non-existent - in rural areas.

${ }^{14}$ The table reports the responses to the question "What was the main reason for coming/changing to the present place of residence."
} 
necessarily have higher returns to their education than non-migrants. To examine issues such as these, a multivariate empirical analysis is called for-to which we therefore now turn.

[Table 3 about here]

\section{Multivariate Analysis}

This section presents and discusses reduced form estimates of wage determinants focusing on the relationship between wages and migration. The estimations are carried out as reduced form $\mathrm{OLS}^{15}$ Mincer-type wage regressions, extended with household migration status (except when conditioning on migrant status) and the share of migrants in the community. In addition to the full sample of adult Ethiopian wage earners, models are also estimated separately for females and males, migrants and non-migrants, and by educational attainment so as to explore the possibility of the wage structure differing across these dimensions-especially regarding the migration and education variables. The main objective here is to determine which part(s) of the Ethiopian work force are particularly affected by migration. All estimations incorporate the survey design - thus making the results nationally representative-by incorporating sampling weights, stratification and clustering (Wooldridge, 2010).

\section{Is there a premium to migration? Does the share of migrants in the current (receiving)} community matter? From Table 4, migration is associated with substantively and statistically significantly higher wages for the full sample and for males, so that adults from households who moved to the area within the past 4 years earn about 10.2 percent more than comparable adults from non-migrant households; for males, the migration premium is substantially higher, at 15.1 percent. ${ }^{16}$ At only 4.1 percentage points, the migration premium for females is much lower; it is also imprecisely measured (high standard error) and therefore not statistically significant from

\footnotetext{
${ }^{15}$ Again, as discussed in Section 2, the potential endogeneity of both labor supply and migration status is a relevant concern in this study - though initial experiments with Heckman-type models to allow labor supply to be endogenous, as well as an instrumental variables strategy in a model where only household level migration was included (using the density of migrant households in the community of residence as identifying instrument) both turned out to support the more straightforward OLS framework.

${ }^{16}$ Using the formula: returns in percent $=\{\exp [$ coefficient $]-1\} * 100$. Using instead Kennedy's (1981) bias correction for dummy variables in semi-logarithmic models does not lead to notably different results- the biascorrected results being 10 percent for the full sample and 15 percent for males, respectively (again, Kennedy's (1981) bias-corrected formula is: Bias-corrected returns in percent $=\{\exp [$ coefficient $-0.5 * \operatorname{Var}(\operatorname{coefficient})]-$ $\left.1\}^{*} 100\right)$. Due to the negligible difference in the results from the two methods here, the subsequently reported migration premium results use the "raw" (non- bias-corrected) migration premium formula.
} 
zero. These estimates are certainly not unrealistic as compared to the findings in the previous literature reviewed previously_with Beegle et al. (2011) estimating a migration premium in the order of 36 percentage-points annual per capita household consumption growth over the thirteenyear period covered by their Tanzanian panel and de Brauw et al. (2013) estimating a migration premium of about 110 percent per capita household consumption for Ethiopia (again using a panel dataset).

Still, given the endogeneity concerns discussed previously, including migrants likely being less risk-averse and more achievement-oriented than non-migrants (both of which are hard to measure, thus likely leading to omitted variables bias) this estimate is likely biased upward. To address this, we suggest using the results from McKenzie et al. (2010), which examine returns to migration using a unique combination of experimental and non-experimental data from New Zealand, to anchor our results. Again, the contexts are obviously very different but at least this can help bounding our results to some extent. Using the main finding from McKenzie et al. (2010) - that non-experimental methods (other than instrumental variables) overstate the gains from migration by $20-82$ percent - it is clear that while our results thus also likely overstate the "true" effect of migration, the net effect of migration on wages if taking the selection-component out is still sizeable. Indeed, taking 20 percentage points as the lower and 82 percent as the upper level of overstatement of the migration premium, the migration premium for the full sample can then be bounded between 5.6 and 8.5 percent and the male migration premium between 8.3 and 12.6 percent — which are still quite large migration premia.

Though the estimate is large, with an expected negative sign, there is no statistically significant association between the share of recent migrants in the community of destination and wages. Further, many of the findings from the empirical human capital literature are seen to hold for Ethiopia, as well. There is a wage gap in wages related to gender, females earning considerably less than males for given characteristics, a concave age-earnings profile, and substantial returns to education. Additionally, education returns increase with education level. The wage structures are also statistically significantly different across females and males overall: performing a Chow-type test for structural break (thus testing whether the interactions in a fully interacted model are jointly zero) yields a p-value less than 0.1 percent. The wage structure therefore differs statistically significantly between females and males. 
[Table 4 about here]

Is the overall wage structure of migrants and non-migrants different?

While only males from migrant households were found to earn substantially more than comparable individuals (males) from non-migrant households, there is still the possibility that the entire returns structure differs systematically between individuals from migrant and nonmigrant households. To examine this further, we estimate the models separately for migrants and non-migrants (see Table 5). From Table 5, female migrants experience higher returns to education than female non-migrants, while the evidence for males is more mixed. Noticeably, for the full sample, the depressing effect of having more migrants in the community is now both large and statistically significant for migrants, while it remains statistically insignificant — and much smaller in substantive terms - for non-migrants.

[Table 5 about here]

We again formally test whether the wage structure differs between migrants and nonmigrants. This yields p-values of 2 percent for the full sample, 7.8 percent for females, and 14.3 percent for males. There is therefore strong evidence for structural differences in the wage structure for wage earners as a whole. Conditioning on gender, however, there is moderate to strong evidence favoring structural differences in the wage structure of female migrants and female non-migrants and weak to no evidence favoring a similar difference in the wage structure for males.

\section{Does the migration-wage association differ across educational attainment?}

To explore whether the migration-wage association differs across educational attainment, we estimate models that condition on educational attainment. Table 6 presents the results pertaining to the migration variable(s) from this exercise (the other explanatory variables were included as before but the results have been excluded to make the table more readable; they are available upon request). Table 6 reveals two striking results. First, the positive premium to householdlevel migration found earlier only "survives" (in both statistical and substantive terms) for the full sample and for males - and only for the group of individuals with above grade 12 completed. Second, the depressing effect of having more migrants in the community found earlier for 
migrants in the full sample turns out to be driven by the less skilled workers: while substantively large for several different education levels, the negative association is only statistically significantly different from zero for individuals with no education (full sample, females, males, non-migrants) and for individuals with grade 1-4 completed (migrants). Perhaps this reflects a migration pattern for low-skilled migrants whereby they migrate to specific areas with high demand for low-skilled workers (who are paid low wages), so that the effect is not so much an effect of the share of migrants per see, but rather the effect of migrants with low-education ending up in specific location (after all we do not know if their wage is higher or lower than any potential wage they could have earned at home). It is also possible, however, that the increased competition from migrants leads to some of the native workers emigrating - so that part of the estimated wage effect is actually due to this "discouraged native worker" effect rather than network effects per se (i.e. the network effect would be biased upward, in this case). Testing for whether the wage structure is also statistically significant as a whole across educational attainment reveals that this is indeed the case: the p-value for joint statistical significance of the interaction terms in a fully interacted model was less than 0.001 in all cases.

In combination, these last results suggest that migration has both winners and losers: the more educated are the winners from increased migration, while the less educated are the losers.

[Table 6 about here]

\section{Conclusion}

This paper examines internal migration in Ethiopia, focusing at the linkages among internal migration, education and wages. Descriptive statistics indicate that migrants are better off than non-migrants on average in terms of both their education and their wages. When moving to the multivariate analysis, these preliminary results are strengthened: not only do migrants also obtain higher wages when other factors (including education) are controlled for, they also obtain higher returns to their education than non-migrant, controlling for other factors.

What does all this mean? In combination, the results suggest that the more educated are the winners from increased migration, while the less educated are the losers. That is, "the winner takes it all": the more educated reap higher returns both from benefitting more from migration and from being better educated to begin with, leaving the less educated - especially among the migrant population - as the losers. 
This result should be of concern to policy makers in Ethiopia, since individuals with low levels of education already comprise a vulnerable group. Focus should therefore be shifted even more towards this group - for example in terms of skills upgrading and education - especially in areas with high levels of in-migration.

Future research may want to extend these analyses to other countries - especially in SubSaharan Africa, where internal migration is an important feature of the labor market. As always, such efforts are data dependent, however. The data examined here provided only a measure of internal migration at the household level, which —our cross-validation efforts notwithstandingis less than ideal. Collecting migration information at the individual level in future surveys for Ethiopia - and other countries - would help us understanding the workings and correlates of internal migration even better. At the same time, it is important that future data collection efforts also emphasize the importance of other important information - including information on wages (for both migrants and non-migrants), the inclusion of which is not necessarily common in current data collection efforts.

\section{References:}

Ajakaiye, Olu, Robert E.B. Lucas, and Joseph T. Karugia (2006) “Africa's Resurgence and International Migration: An Overview," Journal of African Economies 15(2): 141-160.

Becker, Gary. S. (1964) Human Capital, New York: Columbia University Press.

Beegle, Kathleen, Joachim De Weerdt, and Stefan Dercon (2011) "Migration and Economic Mobility in Tanzania: Evidence from a Tracking Survey," The Review of Economics and Statistics 93(3): 1010-1033.

CSA (2002) Ethiopia Child Labour Survey Report 2001, Central Statistical Authority (CSA): Addis Ababa.

de Brauw, Alan and Valerie Mueller (2012) "Do Limitations in Land Rights Transferability Influence Mobility Rates in Ethiopia?" Journal of African Economies 21(4): 548-579.

de Brauw, Alan, Valerie Mueller, and Hak Lim Lee (2014) "The Role of Rural-Urban Migration in the Structural Transformation of Sub-Saharan Africa," World Development 63: 33-42.

de Brauw, Alan, Valerie Mueller, and Tassew Woldehanna (2013) "Does Internal Migration Improve Overall Well-Being in Ethiopia?" Ethiopia Strategy Support Program II Working Paper 55, Washington, DC and Addis Ababa: International Food Policy Research Institute (IFPRI) and Ethiopian Development Research Institute (EDRI). Accessed online 1/24/2015: http://www.ifpri.org/sites/default/files/publications/esspwp55.pdf

Faini, Riccardo C., Jaime de Melo and Klaus Zimmermann (1999) Migration: The Controversies 
and the Evidence, Cambridge: Cambridge University Press.

Gray, Clark and Valerie Mueller (2012) "Drought and Population Mobility in Rural Ethiopia," World Development 40(1): 134-145.

Huber, P. J. (1967) "The Behavior of Maximum Likelihood Estimates under Nonstandard Conditions," In: Proceedings of the Fifth Berkeley Symposium on Mathematical Statistics and Probability Vol. 1, Berkeley, CA: University of California Press.

Kennedy, Peter E. (1981) "Estimation with Correctly Interpreted Dummy Variables in Semilogarithmic Equations," American Economic Review, 71(4): 801.

Kiros, G-E. and M.J. White (2004) "Migration, community context and child immunization in Ethiopia," Social Science and Medicine: 59: 2603-2616.

Lucas, Robert E.B. (1997) "Internal Migration in Developing Countries," in: M. R. Rosenzweig \& Stark, O. (Eds.), Handbook of Population and Family Economics, Vol. 1, Amsterdam: Elsevier.

Mberu, Blessing Uchenna (2006) "Internal migration and household living conditions in Ethiopia," Demographic Research 14: 509-540.

McKenzie, David, John Gibson, and Steven Stillman (2010) "How Important Is Selection? Experimental v. Non-Experimental Measures of the Income Gains from Migration," Journal of the European Economic Association 8: 913-945.

Mincer, Jacob (1974) Schooling, Experience, and Earnings, New York: Columbia University Press.

Munshi, Kaivan (2003) "Networks in the Modern Economy: Mexican Migrants in the United States Labor Market," Quarterly Journal of Economics 118: 549-597.

O'Donnell, Owen, Eddy van Doorslaer, Adam Wagstaff and Magnus Lindelow (2008) Analyzing Health Equity Using Household Survey Data: A Guide to Techniques and Their Implementation, Washington, DC: World Bank.

Psacharopoulos, George (1994) Returns to Investment in Education: A Global Update, World Development 22(9): 1325-1343.

Psacharopoulos, George and Harry Anthony Patrinos (2004) "Returns to Investment in Education: A Further Update," Education Economics 12(2): 111-134.

Stark, O. (1991) The Migration of Labor, Boston: Basil Blackwell.

Stark, O., and Bloom, D. E. (1985) “The New Economics of Labor Migration,” American Economic Review 75(2): 173-178.

White, H. (1980) "A Heteroskedasticity-Consistent Covariance Matrix Estimator and a Direct Test for Heteroskedasticity," Econometrica 48(4): 817-830.

Wooldridge, J.M. (2010) Econometric Analysis of Cross-Section and Panel Data, Cambridge, Massachusetts: The MIT Press.

World Bank (2007) Urban Labor Markets in Ethiopia: Challenges and Prospects" (In Two Volumes) Volume II: Background Papers, Report No. 38665-ET, Poverty Reduction and Economic Management Unit, Africa Region, Washington, D.C.: World Bank. 
Table 1. Incidence of Recent Migration - Total and By Gender, for All Individuals, Adults and Adult Household Heads, LFS 1999 and CLS 2001

\begin{tabular}{lcc|cc}
\hline & & LFS 1999 & \multicolumn{2}{c}{ CLS 2001 } \\
\hline & Mean & 95 percent CI & Mean & 95 percent CI \\
\hline Adults \& children combined: & & & & \\
\hline Full sample & & & & \\
Females & 0.043 & {$[0.039 ; 0.046]$} & 0.025 & {$[0.022 ; 0.028]$} \\
Males & 0.046 & {$[0.043 ; 0.050]$} & 0.024 & {$[0.021 ; 0.027]$} \\
& 0.039 & {$[0.036 ; 0.043]$} & 0.025 & {$[0.022 ; 0.028]$} \\
Adults (15+): & & & & \\
\hline Full sample & & & & \\
Females & 0.057 & {$[0.053 ; 0.061]$} & 0.028 & {$[0.025 ; 0.031]$} \\
Males & 0.061 & {$[0.057 ; 0.066]$} & 0.026 & {$[0.023 ; 0.029]$} \\
& 0.052 & {$[0.048 ; 0.057]$} & 0.029 & {$[0.026 ; 0.033]$} \\
Adult household heads: & & & & \\
\hline Full sample & & & & \\
Females & 0.057 & {$[0.042 ; 0.050]$} & 0.036 & {$[0.032 ; 0.040]$} \\
Males & 0.061 & {$[0.050 ; 0.063]$} & 0.044 & {$[0.038 ; 0.051]$} \\
\hline
\end{tabular}

Notes: Calculations incorporate sampling weights and clustering (Wooldridge, 2010).

Source: Ethiopia Labor Force Survey, 1999, and Ethiopia Child Labor Survey, 2001.

Table 2. Reason for Migration, Full Sample and by Gender

\begin{tabular}{lr|rr}
\hline & All & Females & Males \\
\hline Education & 0.044 & 0.072 & 0.033 \\
Marriage arrangement & 0.008 & 0.006 & 0.009 \\
Marriage dissolution & 0.009 & 0.032 & 0.000 \\
Looking for a job & 0.199 & 0.182 & 0.206 \\
Found a job/transfer & 0.616 & 0.546 & 0.645 \\
Displacement, war, draught & 0.051 & 0.069 & 0.044 \\
Other & 0.073 & 0.094 & 0.064 \\
\hline Total & 1.000 & 1.000 & 1.000 \\
\hline
\end{tabular}

Notes: Sample sizes are 1, 147 observations (all migrants), 349 observations (female migrants), and 798 observations (male migrants). Calculations incorporate sampling weights.

Source: Ethiopia Child Labor Survey, 2001. 
Table 3. Means for Estimation Sample: Full Sample and by Gender and Migrant Status

\begin{tabular}{lr|rr|rr}
\hline & All & Female & Males & Migrants & $\begin{array}{r}\text { Non- } \\
\text { migrants }\end{array}$ \\
\hline Hourly earnings & 3.209 & 3.009 & 3.344 & 4.022 & 3.110 \\
Female & 0.405 & 1.000 & 0.000 & 0.296 & 0.418 \\
Age & 31.982 & 27.773 & 34.841 & 31.072 & 32.092 \\
No education & 0.184 & 0.305 & 0.102 & 0.135 & 0.190 \\
Grade 1-4 & 0.084 & 0.092 & 0.079 & 0.055 & 0.088 \\
Grade 5-8 & 0.186 & 0.154 & 0.207 & 0.148 & 0.190 \\
Grade 9-12 & 0.286 & 0.262 & 0.302 & 0.315 & 0.283 \\
Above grade 12 & 0.237 & 0.167 & 0.285 & 0.327 & 0.226 \\
Lit camp/nonformal & 0.022 & 0.020 & 0.024 & 0.019 & 0.023 \\
Recently migrated & 0.108 & 0.079 & 0.127 & 1.000 & 0.000 \\
Share migrants & 0.085 & 0.082 & 0.087 & 0.177 & 0.074 \\
\hline $\mathrm{N}$ & 10,414 & 4,228 & 6,186 & 1,147 & 9,267 \\
\hline
\end{tabular}

Notes: Calculations incorporate sampling weights.

Source: Ethiopia Child Labor Survey, 2001. 
Table 4. Wage Regressions for Full Sample and Across Gender

\begin{tabular}{|c|c|c|c|}
\hline & Full sample & Females & Males \\
\hline Female & $\begin{array}{l}-0.395^{* * *} \\
{[0.032]}\end{array}$ & & \\
\hline Age & $\begin{array}{l}0.088 * * * \\
{[0.008]}\end{array}$ & $\begin{array}{l}0.087 * * * \\
{[0.015]}\end{array}$ & $\begin{array}{l}0.088 * * * \\
{[0.009]}\end{array}$ \\
\hline Age squared & $\begin{array}{l}-0.001 * * * \\
{[0.000]}\end{array}$ & $\begin{array}{l}-0.001 * * * \\
{[0.000]}\end{array}$ & $\begin{array}{l}-0.001 * * * \\
{[0.000]}\end{array}$ \\
\hline Grade 1-4 & $\begin{array}{l}0.220 * * * \\
{[0.060]}\end{array}$ & $\begin{array}{l}0.178 * * \\
{[0.080]}\end{array}$ & $\begin{array}{l}0.183 * * \\
{[0.085]}\end{array}$ \\
\hline Grade $5-8$ & $\begin{array}{l}0.634 * * * \\
{[0.057]}\end{array}$ & $\begin{array}{l}0.566 * * * \\
{[0.085]}\end{array}$ & $\begin{array}{l}0.581 * * * \\
{[0.079]}\end{array}$ \\
\hline Grade $9-12$ & $\begin{array}{l}1.076 * * * \\
{[0.051]}\end{array}$ & $\begin{array}{l}1.205 * * * \\
{[0.065]}\end{array}$ & $\begin{array}{l}0.907 * * * \\
{[0.077]}\end{array}$ \\
\hline Above grade 12 & $\begin{array}{l}1.638^{* * *} \\
{[0.051]}\end{array}$ & $\begin{array}{l}1.808 * * * \\
{[0.073]}\end{array}$ & $\begin{array}{l}1.471 * * * \\
{[0.072]}\end{array}$ \\
\hline Lit camp/nonformal & $\begin{array}{l}0.099 \\
{[0.110]}\end{array}$ & $\begin{array}{l}-0.066 \\
{[0.157]}\end{array}$ & $\begin{array}{l}0.129 \\
{[0.151]}\end{array}$ \\
\hline Recently migrated & $\begin{array}{l}0.097 * \\
{[0.051]}\end{array}$ & $\begin{array}{l}0.04 \\
{[0.109]}\end{array}$ & $\begin{array}{l}0.141 * * * \\
{[0.053]}\end{array}$ \\
\hline Share migrants & $\begin{array}{l}-0.304 \\
{[0.297]}\end{array}$ & $\begin{array}{l}-0.381 \\
{[0.424]}\end{array}$ & $\begin{array}{l}-0.215 \\
{[0.305]}\end{array}$ \\
\hline Tigray & $\begin{array}{l}0.680 * * * \\
{[0.259]}\end{array}$ & $\begin{array}{l}0.898 * * \\
{[0.353]}\end{array}$ & $\begin{array}{l}0.480 * * \\
{[0.206]}\end{array}$ \\
\hline Affar & $\begin{array}{l}0.502 * * * \\
{[0.174]}\end{array}$ & $\begin{array}{l}0.730 * * * \\
{[0.260]}\end{array}$ & $\begin{array}{l}0.302 * * * \\
{[0.108]}\end{array}$ \\
\hline Amhara & $\begin{array}{l}-0.239 * * * \\
{[0.052]}\end{array}$ & $\begin{array}{l}-0.318^{* * *} \\
{[0.085]}\end{array}$ & $\begin{array}{l}-0.189 * * * \\
{[0.060]}\end{array}$ \\
\hline Oromyia & $\begin{array}{l}-0.214 * * * \\
{[0.049]}\end{array}$ & $\begin{array}{l}-0.222 * * * \\
{[0.068]}\end{array}$ & $\begin{array}{l}-0.238 * * * \\
{[0.058]}\end{array}$ \\
\hline Somali & $\begin{array}{l}0.11 \\
{[0.104]}\end{array}$ & $\begin{array}{l}0.263 * * * \\
{[0.081]}\end{array}$ & $\begin{array}{l}0.016 \\
{[0.161]}\end{array}$ \\
\hline Benishangul & $\begin{array}{l}-0.072 \\
{[0.090]}\end{array}$ & $\begin{array}{l}0.057 \\
{[0.244]}\end{array}$ & $\begin{array}{l}-0.162 * * \\
{[0.069]}\end{array}$ \\
\hline SNNP & $\begin{array}{l}-0.190 * * * \\
{[0.054]}\end{array}$ & $\begin{array}{l}-0.129 \\
{[0.091]}\end{array}$ & $\begin{array}{l}-0.239 * * * \\
{[0.062]}\end{array}$ \\
\hline Gambella & $\begin{array}{l}0.082 \\
{[0.083]}\end{array}$ & $\begin{array}{l}0.236 * * \\
{[0.093]}\end{array}$ & $\begin{array}{l}0.02 \\
{[0.109]}\end{array}$ \\
\hline Harari & $\begin{array}{l}-0.017 \\
{[0.040]}\end{array}$ & $\begin{array}{l}0.027 \\
{[0.059]}\end{array}$ & $\begin{array}{l}-0.059 \\
{[0.052]}\end{array}$ \\
\hline Dire Dawa & $\begin{array}{l}0.133 * \\
{[0.075]}\end{array}$ & $\begin{array}{l}0.272 * * \\
{[0.110]}\end{array}$ & $\begin{array}{l}0.026 \\
{[0.072]}\end{array}$ \\
\hline Constant & $\begin{array}{l}-2.105 * * * \\
{[0.130]}\end{array}$ & $\begin{array}{l}-2.542 * * * \\
{[0.217]}\end{array}$ & $\begin{array}{l}-1.951 * * * \\
{[0.181]}\end{array}$ \\
\hline $\begin{array}{l}\mathrm{R}^{2} \\
\mathrm{~N}\end{array}$ & $\begin{array}{l}0.44 \\
10,414 \\
\end{array}$ & $\begin{array}{l}0.39 \\
4,228 \\
\end{array}$ & $\begin{array}{l}0.37 \\
6,186 \\
\end{array}$ \\
\hline
\end{tabular}

Notes: Robust Huber-White (Huber, 1967; White, 1980) standard errors, adjusted for within-cluster correlation/clustering (Wooldridge, 2010), in brackets under parameter estimates. *: statistically significant at 10 percent; **: statistically significant at 5 percent; ***: statistically significant at 1 percent. Reference groups are "No education" (education), and "Addis Ababa" (region). Chow-type test for sample split across gender: $\mathrm{F}(19,505)=3.90$, P-value $<0.001$.

Source: Ethiopia Child Labor Survey, 2001. 
Table 5. Wage Regressions By Migrant Status: Full Sample and Across Gender

\begin{tabular}{|c|c|c|c|c|c|c|}
\hline & \multicolumn{2}{|c|}{ Full sample } & \multicolumn{2}{|c|}{ Females } & \multicolumn{2}{|c|}{ Males } \\
\hline & Migrants & $\begin{array}{l}\text { Non- } \\
\text { migrants }\end{array}$ & Migrants & $\begin{array}{l}\text { Non- } \\
\text { migrants }\end{array}$ & Migrants & $\begin{array}{l}\text { Non- } \\
\text { migrants }\end{array}$ \\
\hline Female & $\begin{array}{l}-0.399 * * * \\
{[0.113]}\end{array}$ & $\begin{array}{l}-0.393 * * * \\
{[0.033]}\end{array}$ & & & & \\
\hline Age & $\begin{array}{l}0.116^{* * *} \\
{[0.024]}\end{array}$ & $\begin{array}{l}0.087 * * * \\
{[0.008]}\end{array}$ & $\begin{array}{l}0.156^{* *} \\
{[0.061]}\end{array}$ & $\begin{array}{l}0.085 * * * \\
{[0.015]}\end{array}$ & $\begin{array}{l}0.105 * * * \\
{[0.027]}\end{array}$ & $\begin{array}{l}0.087 * * * \\
{[0.010]}\end{array}$ \\
\hline Age squared & $\begin{array}{l}-0.001 * * * \\
{[0.000]}\end{array}$ & $\begin{array}{l}-0.001 * * * \\
{[0.000]}\end{array}$ & $\begin{array}{l}-0.002 * * \\
{[0.001]}\end{array}$ & $\begin{array}{l}-0.001 * * * \\
{[0.000]}\end{array}$ & $\begin{array}{l}-0.001 * * * \\
{[0.000]}\end{array}$ & $\begin{array}{l}-0.001 * * * \\
{[0.000]}\end{array}$ \\
\hline Grade 1-4 & $\begin{array}{l}0.521^{*} \\
{[0.294]}\end{array}$ & $\begin{array}{l}0.199 * * * \\
{[0.062]}\end{array}$ & $\begin{array}{l}0.618^{*} \\
{[0.350]}\end{array}$ & $\begin{array}{l}0.152^{*} \\
{[0.084]}\end{array}$ & $\begin{array}{l}0.18 \\
{[0.433]}\end{array}$ & $\begin{array}{l}0.186^{* *} \\
{[0.090]}\end{array}$ \\
\hline Grade 5-8 & $\begin{array}{l}0.871 * * * \\
{[0.241]}\end{array}$ & $\begin{array}{l}0.618^{* * *} \\
{[0.059]}\end{array}$ & $\begin{array}{l}1.082 * * \\
{[0.482]}\end{array}$ & $\begin{array}{l}0.525 * * * \\
{[0.092]}\end{array}$ & $\begin{array}{l}0.471 \\
{[0.324]}\end{array}$ & $\begin{array}{l}0.596 * * * \\
{[0.086]}\end{array}$ \\
\hline Grade $9-12$ & $\begin{array}{l}1.328 * * * \\
{[0.221]}\end{array}$ & $\begin{array}{l}1.053 * * * \\
{[0.054]}\end{array}$ & $\begin{array}{l}1.461 * * * \\
{[0.272]}\end{array}$ & $\begin{array}{l}1.181 * * * \\
{[0.070]}\end{array}$ & $\begin{array}{l}0.935^{* * *} \\
{[0.310]}\end{array}$ & $\begin{array}{l}0.901 * * * \\
{[0.081]}\end{array}$ \\
\hline Above grade 12 & $\begin{array}{l}1.811 * * * \\
{[0.209]}\end{array}$ & $\begin{array}{l}1.619 * * * \\
{[0.054]}\end{array}$ & $\begin{array}{l}2.095 * * * \\
{[0.277]}\end{array}$ & $\begin{array}{l}1.778 * * * \\
{[0.079]}\end{array}$ & $\begin{array}{l}1.401 * * * \\
{[0.299]}\end{array}$ & $\begin{array}{l}1.476 * * * \\
{[0.078]}\end{array}$ \\
\hline Lit camp/nonformal & $\begin{array}{l}0.505^{*} \\
{[0.269]}\end{array}$ & $\begin{array}{l}0.076 \\
{[0.116]}\end{array}$ & $\begin{array}{l}1.212 \\
{[0.914]}\end{array}$ & $\begin{array}{l}-0.104 \\
{[0.160]}\end{array}$ & $\begin{array}{l}0.022 \\
{[0.355]}\end{array}$ & $\begin{array}{l}0.149 \\
{[0.166]}\end{array}$ \\
\hline Share migrants & $\begin{array}{l}-0.969^{* *} \\
{[0.408]}\end{array}$ & $\begin{array}{l}-0.15 \\
{[0.333]}\end{array}$ & $\begin{array}{l}-1.226 \\
{[0.806]}\end{array}$ & $\begin{array}{l}-0.206 \\
{[0.461]}\end{array}$ & $\begin{array}{l}-0.705 \\
{[0.530]}\end{array}$ & $\begin{array}{l}-0.102 \\
{[0.351]}\end{array}$ \\
\hline Tigray & $\begin{array}{l}0.729^{* *} \\
{[0.310]}\end{array}$ & $\begin{array}{l}0.667 * * \\
{[0.261]}\end{array}$ & $\begin{array}{l}1.172 * * \\
{[0.484]}\end{array}$ & $\begin{array}{l}0.822 * * \\
{[0.335]}\end{array}$ & $\begin{array}{l}0.395 \\
{[0.300]}\end{array}$ & $\begin{array}{l}0.511^{* *} \\
{[0.219]}\end{array}$ \\
\hline Affar & $\begin{array}{l}0.167 \\
{[0.178]}\end{array}$ & $\begin{array}{l}0.554 * * * \\
{[0.194]}\end{array}$ & $\begin{array}{l}-0.033 \\
{[0.376]}\end{array}$ & $\begin{array}{l}0.783^{* * * *} \\
{[0.256]}\end{array}$ & $\begin{array}{l}0.179 \\
{[0.233]}\end{array}$ & $\begin{array}{l}0.334 * * \\
{[0.129]}\end{array}$ \\
\hline Amhara & $\begin{array}{l}-0.041 \\
{[0.207]}\end{array}$ & $\begin{array}{l}-0.279^{* * *} \\
{[0.061]}\end{array}$ & $\begin{array}{l}-0.111 \\
{[0.422]}\end{array}$ & $\begin{array}{l}-0.351^{* * *} \\
{[0.104]}\end{array}$ & $\begin{array}{l}-0.02 \\
{[0.216]}\end{array}$ & $\begin{array}{l}-0.231^{* * *} \\
{[0.063]}\end{array}$ \\
\hline Oromyia & $\begin{array}{l}-0.18 \\
{[0.144]}\end{array}$ & $\begin{array}{l}-0.226^{* * *} \\
{[0.053]}\end{array}$ & $\begin{array}{l}-0.186 \\
{[0.235]}\end{array}$ & $\begin{array}{l}-0.235^{* * *} \\
{[0.068]}\end{array}$ & $\begin{array}{l}-0.249 \\
{[0.196]}\end{array}$ & $\begin{array}{l}-0.246^{* * *} \\
{[0.064]}\end{array}$ \\
\hline Somali & $\begin{array}{l}-0.081 \\
{[0.182]}\end{array}$ & $\begin{array}{l}0.17 \\
{[0.110]}\end{array}$ & $\begin{array}{l}0.344 * \\
{[0.203]}\end{array}$ & $\begin{array}{l}0.268 * * * \\
{[0.088]}\end{array}$ & $\begin{array}{l}-0.161 \\
{[0.210]}\end{array}$ & $\begin{array}{l}0.11 \\
{[0.188]}\end{array}$ \\
\hline Benishangul & $\begin{array}{l}0.05 \\
{[0.186]}\end{array}$ & $\begin{array}{l}-0.103 \\
{[0.105]}\end{array}$ & $\begin{array}{l}-0.231 \\
{[0.273]}\end{array}$ & $\begin{array}{l}0.134 \\
{[0.267]}\end{array}$ & $\begin{array}{l}0.095 \\
{[0.258]}\end{array}$ & $\begin{array}{l}-0.231 * * * \\
{[0.077]}\end{array}$ \\
\hline SNNP & $\begin{array}{l}-0.134 \\
{[0.191]}\end{array}$ & $\begin{array}{l}-0.196^{* * *} \\
{[0.053]}\end{array}$ & $\begin{array}{l}-0.121 \\
{[0.263]}\end{array}$ & $\begin{array}{l}-0.13 \\
{[0.094]}\end{array}$ & $\begin{array}{l}-0.199 \\
{[0.262]}\end{array}$ & $\begin{array}{l}-0.247^{* * *} \\
{[0.059]}\end{array}$ \\
\hline Gambella & $\begin{array}{l}0.012 \\
{[0.158]}\end{array}$ & $\begin{array}{l}0.099 \\
{[0.091]}\end{array}$ & $\begin{array}{l}0.161 \\
{[0.260]}\end{array}$ & $\begin{array}{l}0.249^{* *} \\
{[0.106]}\end{array}$ & $\begin{array}{l}-0.14 \\
{[0.224]}\end{array}$ & $\begin{array}{l}0.047 \\
{[0.122]}\end{array}$ \\
\hline Harari & $\begin{array}{l}0.055 \\
{[0.201]}\end{array}$ & $\begin{array}{l}-0.022 \\
{[0.039]}\end{array}$ & $\begin{array}{l}-0.11 \\
{[0.511]}\end{array}$ & $\begin{array}{l}0.034 \\
{[0.058]}\end{array}$ & $\begin{array}{l}0.089 \\
{[0.236]}\end{array}$ & $\begin{array}{l}-0.071 \\
{[0.055]}\end{array}$ \\
\hline Dire Dawa & $\begin{array}{l}0.064 \\
{[0.186]}\end{array}$ & $\begin{array}{l}0.131^{*} \\
{[0.077]}\end{array}$ & $\begin{array}{l}-0.126 \\
{[0.345]}\end{array}$ & $\begin{array}{l}0.275^{* *} \\
{[0.112]}\end{array}$ & $\begin{array}{l}0.03 \\
{[0.260]}\end{array}$ & $\begin{array}{l}0.02 \\
{[0.075]}\end{array}$ \\
\hline Constant & $\begin{array}{l}-2.562 * * * \\
{[0.461]}\end{array}$ & $\begin{array}{l}-2.082 * * * \\
{[0.133]}\end{array}$ & $\begin{array}{l}-3.606^{* * *} \\
{[0.802]}\end{array}$ & $\begin{array}{l}-2.502 * * * \\
{[0.226]}\end{array}$ & $\begin{array}{l}-1.988 * * * \\
{[0.703]}\end{array}$ & $\begin{array}{l}-1.943 * * * \\
{[0.183]}\end{array}$ \\
\hline $\begin{array}{l}\mathrm{R}^{2} \\
\mathrm{~N}\end{array}$ & $\begin{array}{l}0.45 \\
1,147\end{array}$ & $\begin{array}{l}0.44 \\
9,267\end{array}$ & $\begin{array}{l}0.42 \\
349\end{array}$ & $\begin{array}{l}0.39 \\
3,879\end{array}$ & $\begin{array}{l}0.37 \\
798\end{array}$ & $\begin{array}{l}0.36 \\
5,388\end{array}$ \\
\hline
\end{tabular}

Notes: Robust Huber-White (Huber, 1967; White, 1980) standard errors, adjusted for within-cluster correlation/clustering (Wooldridge, 2010), in brackets under parameter estimates. *: statistically significant at 10 percent; **: statistically significant at 5 percent; ***: statistically significant at 1 percent. Reference groups are "No education" (education), and "Addis Ababa" 
(region). Chow-type tests for sample split: $\mathrm{F}(19,505)=1.80, \mathrm{P}$-value $=0.020$ (full sample); $\mathrm{F}(18,506)=1.52, \mathrm{P}$-value $=0.078$ (females); F(18, 506) = 1.37, P-value $=0.143$ (males).

Source: Ethiopia Child Labor Survey, 2001.

Table 6. Wage Regressions by Educational Attainment: Full Sample, Across Gender, and Across Migrant Status

\begin{tabular}{|c|c|c|c|c|c|c|}
\hline & No education & Grade 1-4 & Grade 5-8 & Grade 9-12 & $>$ Grade 12 & Non-formal \\
\hline \multicolumn{7}{|l|}{ (i) Full sample: } \\
\hline \multirow[t]{2}{*}{ Recently migrated } & 0.003 & 0.155 & 0.035 & 0.073 & $0.126^{*}$ & 0.074 \\
\hline & {$[0.225]$} & {$[0.257]$} & {$[0.145]$} & {$[0.075]$} & {$[0.068]$} & {$[0.242]$} \\
\hline \multirow[t]{2}{*}{ Share migrants } & $-1.744 * * *$ & -0.345 & -0.274 & 0.166 & 0.113 & 0.472 \\
\hline & {$[0.498]$} & {$[0.654]$} & {$[0.782]$} & {$[0.391]$} & {$[0.295]$} & {$[2.242]$} \\
\hline $\mathrm{R}^{2}$ & 0.18 & 0.32 & 0.2 & 0.18 & 0.16 & 0.29 \\
\hline $\mathrm{N}$ & 1,810 & 861 & 2,133 & 3,187 & 2,206 & 217 \\
\hline \multicolumn{7}{|l|}{ (ii) Females: } \\
\hline \multirow[t]{2}{*}{ Recently migrated } & -0.112 & 0.148 & 0.404 & -0.021 & 0.005 & 1.24 \\
\hline & {$[0.303]$} & {$[0.367]$} & {$[0.446]$} & {$[0.158]$} & {$[0.087]$} & [1.203] \\
\hline \multirow[t]{2}{*}{ Share migrants } & $-1.527 * *$ & 0.648 & -1.169 & 0.153 & 0.308 & -0.984 \\
\hline & {$[0.712]$} & [1.185] & [1.095] & {$[0.575]$} & {$[0.342]$} & [3.058] \\
\hline $\mathrm{R}^{2}$ & 0.12 & 0.28 & 0.17 & 0.21 & 0.12 & 0.12 \\
\hline $\mathrm{N}$ & 1,237 & 391 & 747 & 1,167 & 612 & 74 \\
\hline \multicolumn{7}{|l|}{ (iii) Males: } \\
\hline \multirow[t]{2}{*}{ Recently migrated } & 0.34 & 0.23 & -0.134 & 0.133 & $0.160 * *$ & -0.091 \\
\hline & {$[0.366]$} & {$[0.271]$} & {$[0.187]$} & {$[0.084]$} & {$[0.079]$} & {$[0.266]$} \\
\hline \multirow[t]{2}{*}{ Share migrants } & $-2.599 * * *$ & -0.812 & 0.136 & 0.145 & 0.027 & 0.678 \\
\hline & {$[0.829]$} & {$[0.743]$} & {$[0.823]$} & {$[0.408]$} & {$[0.315]$} & [2.694] \\
\hline $\mathrm{R}^{2}$ & 0.18 & 0.27 & 0.12 & 0.12 & 0.14 & 0.34 \\
\hline $\mathrm{N}$ & 573 & 470 & 1,386 & 2,020 & 1,594 & 143 \\
\hline \multicolumn{7}{|l|}{ (iv) Migrants: } \\
\hline \multirow[t]{2}{*}{ Share migrants } & -2.32 & $-3.077 * *$ & -1.794 & -0.037 & -0.46 & -2.75 \\
\hline & [1.863] & {$[1.252]$} & [1.599] & {$[0.462]$} & {$[0.653]$} & [2.904] \\
\hline $\mathrm{R}^{2}$ & 0.3 & 0.26 & 0.25 & 0.33 & 0.23 & 0.56 \\
\hline $\mathrm{N}$ & 143 & 80 & 197 & 349 & 359 & 19 \\
\hline \multicolumn{7}{|l|}{ (v) Non-migrants: } \\
\hline \multirow[t]{2}{*}{ Share migrants } & $-1.612 * * *$ & 0.012 & 0 & 0.331 & 0.265 & 0.313 \\
\hline & {$[0.561]$} & {$[0.703]$} & {$[0.826]$} & {$[0.461]$} & {$[0.300]$} & {$[2.488]$} \\
\hline $\mathrm{R}^{2}$ & 0.17 & 0.35 & 0.21 & 0.17 & 0.16 & 0.31 \\
\hline $\mathrm{N}$ & 1,667 & 781 & 1,936 & 2,838 & 1,847 & 198 \\
\hline
\end{tabular}

Notes: Robust Huber-White (Huber, 1967; White, 1980) standard errors, adjusted for within-cluster correlation/clustering (Wooldridge, 2010), in brackets under parameter estimates. *: statistically significant at 10 percent; **: statistically significant at 5 percent; ***: statistically significant at 1 percent. Other explanatory variables as in Tables 4 and 5 . Chow-type test for sample splits: $\mathrm{F}(74,450)=5.81$, P-value $<0.001$ (full sample); F(68, 456) = 11.65, P-value $<0.001$ (females); F(69, 455) = 3.49, Pvalue $<0.001$ (males); $\mathrm{F}(65,459)=12.33$, P-value $<0.001$ (migrants); $\mathrm{F}(69,455)=4.53$, P-value $<0.001$ (non-migrants). Source: Ethiopia Child Labor Survey, 2001. 